\title{
SubPrime Foreclosures AND THE 2005 BANKRUPTCY REFORM
}

- After the bankruptcy abuse reform (BAR) took effect in October 2005, foreclosures on subprime mortgages surged nationwide.

- Prior to BAR, overly indebted borrowers could file bankruptcy to free up income to pay their mortgage by discharging unsecured debts; BAR eliminated that option for better-off filers through a means test and other requirements, making it more difficult to save one's home by filing bankruptcy.

- A study of the reform suggests that BAR was associated with more subprime foreclosures; BAR's effects were greater in states with high bankruptcy exemptions, as theory predicts.

- For a state with an average home equity exemption, the subprime foreclosure rate after BAR rose 11 percent relative to average before the reform; given the number of subprime mortgages nationwide, that translates into 29,000 additional subprime foreclosures per quarter nationwide.

\section{INTRODUCTION}

T $s$ it just coincidence that subprime foreclosures surged right after the bankruptcy abuse reform (BAR) took effect in

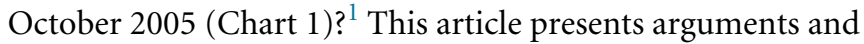
evidence suggesting that it is not. Before BAR, any household could file Chapter 7 bankruptcy and have its credit card and other unsecured debts discharged. By sidestepping their unsecured debts, households retained more income to pay their secured debts, such as mortgages. BAR blocks that maneuver by presenting a variety of obstacles, including a means test that forces better-off households that demand bankruptcy protection to file Chapter 13, where they must continue paying unsecured lenders. ${ }^{2}$ When the means test binds, cash-flow-constrained mortgagors who might have saved their home by filing Chapter 7 are more likely to face foreclosure.

Legal scholars and practitioners have long recognized how filing Chapter 7 and discharging unsecured debts can help avert foreclosure:

... many debtors file bankruptcy precisely so that they can pay their mortgage . . . by discharging other debts (Berkowitz and Hynes 1999, p. 3). ${ }^{3}$

${ }^{1}$ The full name of the reform is the Bankruptcy Abuse Prevention and Consumer Protection Act (BAPCPA). We prefer BAR over BAPCPA because it is pronounceable and because abuse prevention came first (White 2006).

${ }^{2}$ Chapters 7 and 13 are described in more detail in Section 2.

The authors thank James Green, Christer Huffington, Carrie Irwin, Munish Jain, Brian Melzer, and Edward Morrison for helpful comments as well as colleagues and seminar participants at Brown University, the Federal Reserve Bank of New York, the Board of Governors of the Federal Reserve System, the Financial Intermediation Research Society, and the Federal Reserve Bank of Chicago's Bank Structure Conference. An earlier version of this article was circulated as "Seismic Effects of the Bankruptcy Reform." The views expressed are those of the authors and do not necessarily reflect the position of the Federal Reserve Bank of New York, the Federal Reserve System, Harvard University, or the University of California at Berkeley. 
Chart 1

Subprime Foreclosures Rise after BAR

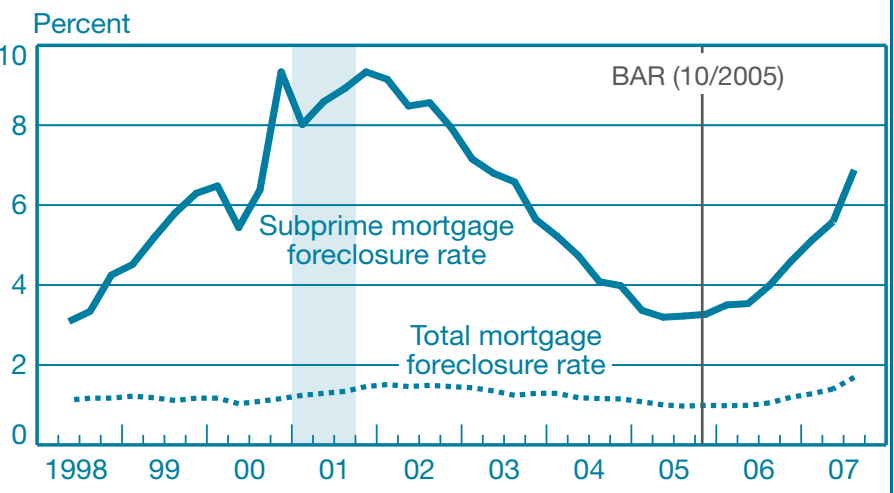

Source: Mortgage Bankers Association.

Notes: BAR is bankruptcy abuse reform. The solid line shows outstanding subprime mortgages in foreclosure in the United States; the dashed line shows outstanding total mortgages in foreclosure in the United States. The vertical band indicates an NBER recession.

If ... the value of your home is covered by your state's homestead exemption, Chapter 7 may be the way to go ... by getting rid of most of your other debts, keeping up the mortgage will be just that much easier (Caher and Caher 2006, p. 190).

Our hypothesis follows directly from the first observation; if some households demand Chapter 7 protection to avoid foreclosure, limiting access to it should increase foreclosures. Our identification strategy follows from the second observation; limiting access to Chapter 7 should have a greater effect in states with high home equity exemptions. ${ }^{4}$ Bankruptcy exemptions are the opposite of collateral-they determine how much home equity Chapter 7 filers can keep from unsecured creditors. We reason that homeowners in states with low home equity exemptions are less likely to demand Chapter 7 , so the means test is less likely to bind in those states. In textbook terms, we identify BAR as a contraction in the "supply" of bankruptcy protection, and we predict a larger impact on foreclosures in states with high exemptions, and hence high "demand" for Chapter 7.

We extend our identification strategy by looking for differential effects of BAR across different classes of household

\footnotetext{
${ }^{3}$ Consistent with the argument, Berkowitz and Hynes (1999) estimate that mortgage rates and the probability of applicants being turned down for mortgages are declining in the level of homestead exemptions.

${ }^{4}$ White and Zhu (2008) find that a substantial fraction of Delaware filers in 2006 were bound by the means test. Of 586 households that filed Chapter 13, 22 percent did not pass the means test and 89 percent owed unsecured debt. Among the 90 percent of Chapter 13 filers that actually filed payment plans, 38 percent committed to repay unsecured debts. The latter represent payments that were potentially avoidable under Chapter 7 before BAR.
}

credit. We expect BAR to reduce delinquency rates on unsecured loans in states with high exemptions because lenders in those states were most exposed to losses from bankruptcy before the reform. We contend that BAR will be unrelated to prime mortgage foreclosures because prime mortgagors are, by definition, unlikely to demand bankruptcy, regardless of exemptions.

We test our predictions by using difference-in-difference regressions of mortgage foreclosure and loan delinquency rates estimated using state-level quarterly data from 1998:1 to 2007:3. The results are largely consistent with our predictions. Given home price appreciation and economic conditions, we find that the increase in subprime foreclosures after BAR was significantly higher in states with higher home equity exemptions. Prime foreclosure rates, by contrast, were unrelated to BAR. In still starker contrast, delinquency rates on unsecured personal loans, which were made more secure under BAR, decreased more after the reform in states with higher home equity exemptions.

The estimated impact of BAR on subprime foreclosures is substantial. For a state with average home equity exemptions, the average subprime foreclosure rate over the seven quarters after BAR was 11 percent higher than the average rate before BAR. This translates to about 29,000 more subprime foreclosures nationwide per quarter attributable to the reform. ${ }^{5}$

Our study adds another candidate to the list of factors that may have triggered the destabilizing surge in subprime foreclosures, including declining home prices (Gerardi, Rosen, and Willen 2007), expanded mortgage supply (Mian and Sufi 2009), looser lending standards (Dell'Ariccia, Igan, and Laeven 2008; Demyanyk and Van Hemert 2007), and agency problems associated with securitization (Keys et al. 2010). Beyond those "usual suspects," we conclude that the bankruptcy reform also played a role.

Although we study foreclosures, the mechanism by which we hypothesize that BAR affects foreclosures begins with delinquency and borrower behavior. Put bluntly, BAR increases the incentives of some cash-flow-constrained mortgagors to quit paying their mortgage-rather than quit paying some other debts and use the cash flow freed up to stay current on their mortgage instead. ${ }^{6}$ It does not, to our knowledge, increase the incentive for lenders to foreclose on

${ }^{5}$ BAR may have indirectly contributed to foreclosures via lower home prices. To the extent that cash-flow-constrained borrowers were forced to sell their homes in lieu of filing Chapter 7, the downward pressure on home prices would contribute to foreclosures by leading to "underwater" mortgages.

${ }^{6}$ Delinquent borrowers may have several options that avert foreclosure. They may be able to execute a deed in lieu of foreclosure, or short-sell the house, or modify their mortgage. Or they may be willing and able to reduce their spending enough to fulfill all their obligations. Delinquent borrowers without any of those or any other options will wind up in foreclosure, so those worst cases are the ones we study. 
TABLE 1

How BAR Affects Debtors and Creditors, by Bankruptcy Law Chapter

\begin{tabular}{lll} 
Category & Pre-BAR & Post-BAR \\
\hline Chapter 7 or 13 determined by & Filer & Means test \\
Chapter 13 repayment plan determined by & Filer & Means test \\
Income lenders can claim in Chapter 7 (Chapter 13) & 0 (per plan) & 0 (per means test) \\
$\begin{array}{l}\text { Days financed car buyer must wait to "cram" loan } \\
\text { Home equity lenders can claim in Chapter 7 (Chapter 13) }\end{array}$ & 0 & 910 \\
Fees + estimated legal costs to file Chapter 7 & & Table 3 or \$125,000 $(0)$ \\
$\quad$ Chapter 13) (thousands of dollars) & & \\
Months between filing and discharge in Chapter 7 (Chapter 13) & $0.6(1.6)$ & $2.3+/-0.5(3.2+/-0.5)$ \\
Unsecured debts discharged in Chapter 7 (Chapter 13) & All - priority (all - priority plus) & $6^{\mathrm{d}}(60)$ \\
Years before refiling permitted in Chapter 7 (Chapter 13) & $6(0.5)$ & Less (less) \\
"Chapter 20" = Chapter 7 + Chapter 13 permitted? & Yes & $8(2)$ \\
Months of credit counseling required before filing & 0 & No
\end{tabular}

Sources: White (2007); CCH (2005).

Notes: BAR is bankruptcy abuse reform. Debtors file bankruptcy to protect themselves from creditors and debt collectors. Secured creditors are entitled to security even in bankruptcy, but credit card and other unsecured debt may be discharged. The disposition of a filer's debts and wealth differs by chapter of the bankruptcy law. Chapter 7 (liquidation) protects all income but not all assets; Chapter 13 (rescheduling) protects all assets but not all income.

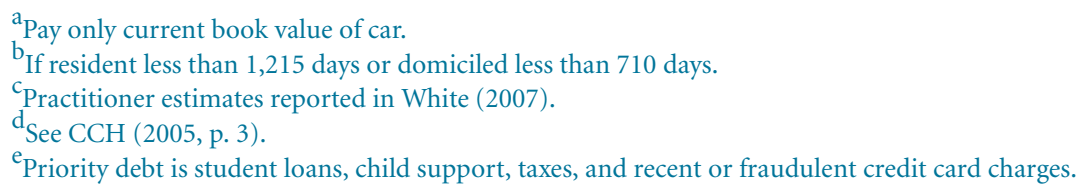

a delinquent borrower. We study foreclosures instead of delinquency nevertheless because foreclosures seem like the ultimate outcome of interest.

To say the reform was associated with more subprime foreclosures is not to say that it did not serve its intended, first purpose of curbing bankruptcy abuse. The strategy that BAR precludes in some cases is defaulting on unsecured debts in order to make it easier to pay secured debts. If that amounts to "robbing" Peter to pay Paul, then the reform may have worked.

It could certainly be said that the timing of the reform was unlucky, coming as it did near the end of housing boom characterized by lax lending standards and regulation. No doubt those initial conditions amplified the impact of BAR on foreclosures. It is possible that the reform was wise policy that simply came at a bad time. ${ }^{7}$

The next section elaborates on how BAR reduced the supply of bankruptcy protection and presents some circumstantial evidence consistent with our hypothesis. Section 3 shows how the means test is more likely to bind (and thus increase foreclosures) in states with high home equity exemptions. In Section 4, we present regression evidence suggesting that BAR did in fact contribute to the surge in subprime foreclosures. Section 5 concludes.

\footnotetext{
${ }^{7}$ In a longer version of this article (Morgan, Iverson, and Botsch 2008), we show that an upside of BAR was cheaper auto credit.
}

\section{BACKGROUND ON BANKRUPTCY AND BAR}

Bankruptcy is court protection of debtors from creditors and debt collectors. While a person is in bankruptcy, a judge stays all collection efforts-foreclosure, repossession of other assets, civil suits, garnishment of wages, and dunning — while the court determines which debts are discharged (forgiven) and which debts the borrower must repay from asset sales or future income. That division depends on which chapter of the bankruptcy law the borrower files under and the bankruptcy exemptions in the filer's state. Under Chapter 13 (rescheduling), filers get to keep all of their assets but commit to continue paying creditors out of future income for three to five years. Under Chapter 7 (liquidation), filers keep all of their future income but lose any home equity that is not exempt under their state's bankruptcy law. Any unsecured debts, including credit card debt and personal loans, that are not paid from the proceeds of liquidation are discharged. ${ }^{8}$ Importantly, the discharge of unsecured debts under Chapter 7 leaves more income to pay a mortgage.

Table 1 summarizes how BAR changed filers' bankruptcy options. While virtually all of the reform's changes raised the

${ }^{8}$ Note that mortgage lenders' claims are secured (nondischargeable) under either chapter. 
ChART 2

Households Rush to File Chapter 7 before BAR

Bankruptcy filings per 10,000 persons

relative to forecasted trend
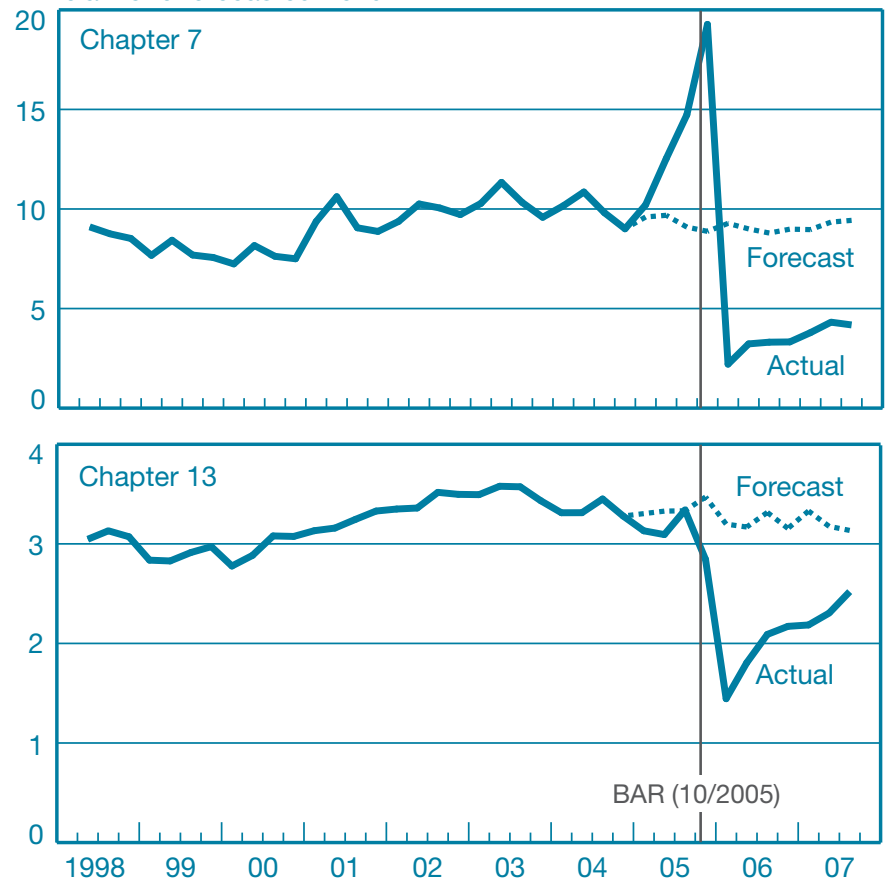

Source: Authors' calculations.

Notes: BAR is bankruptcy abuse reform. The forecast was generated from a vector autoregression model comprising two lags each of bankruptcy filings, the unemployment rate, house price appreciation, and the per capita income annual growth rate. We created the forecast by iteratively running the model and forecasting bankruptcy filings one quarter ahead for each state separately. For each step, we replaced the actual value of bankruptcy filings with the estimated value. Bankruptcy filings per 10,000 persons were averaged across the fifty states and Washington, D.C.

cost of filing or reduced the benefit (protection), the means test may have been the most important change. Before BAR, filers could choose which chapter to file. Now, only filers with income in the previous six months below the state median automatically qualify for Chapter 7 and the discharge. Under Chapter 13, better-off filers whose means (defined as income minus expenses recognized by the Internal Revenue Service, payments to secured creditors, and priority payments) exceed $\$ 166.67$ per month must continue making payments to unsecured creditors for five years. ${ }^{9}$ If Chapter 13 filers fail to make payments, the bankruptcy stay is removed and creditors can resume collection efforts, including foreclosure. ${ }^{10}$

\footnotetext{
${ }^{9}$ Filers with monthly means between $\$ 166.67$ and $\$ 100$ cannot file Chapter 7 if their means exceed 25 percent of their unsecured debts. Filers with means less than $\$ 100$ per month may file Chapter 7. See http://www.usdoj.gov/ust/eo/ bapcpa/meanstesting.htm.

${ }^{10}$ Note that BAR does not change or preempt state home equity exemptions, except for new homebuyers or newly domiciled residents. Our identification strategy does not assume that exemptions were changed.
}

Chart 3

Subprime Mortgages in Bankruptcy Are More Likely to Face Foreclosure after BAR

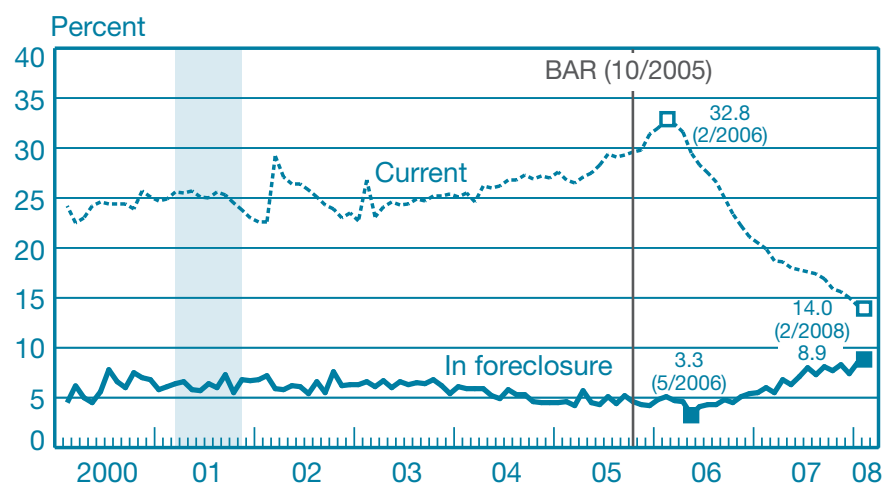

Source: Credit Suisse (2007); data updated by authors.

Notes: BAR is bankruptcy abuse reform. The chart shows the percentage of securitized subprime mortgages-where borrowers are in bankruptcy at month $t$-1-that are either current or in foreclosure at month $t$, weighted by outstanding balance at time $t$. The vertical band indicates an NBER recession.

Before testing our hypothesis formally, we note some circumstantial evidence in support of it. Chart 2 shows that filing rates under either chapter remain lower than one would predict given economic and housing market conditions. Note also that the ratio of filings (Chapter 7/Chapter 13) fell from about $3(10 / 3.25)$ in 2004:4 to $2(5 / 2.5)$ in 2007:3. The means test and other elements of the reform appeared to have lowered aggregate bankruptcy "supply" and the relative demand for Chapter $7 .{ }^{11}$

Shortly after BAR took effect, subprime borrowers in bankruptcy (under either chapter) in a given month were only about half as likely to remain current on their mortgages by the following month and twice as likely to be foreclosed upon (Chart 3). This dramatic reversal is consistent with the premise that bankruptcy became less protective after BAR, though there could have been other factors-falling home prices, for example-that were operating. ${ }^{12}$

Chart 4 demonstrates how higher Chapter 7 filings tend to improve the performance of mortgages relative to that of credit card loans, consistent with the premise that filing Chapter 7 is

${ }^{11}$ We know from other evidence that those exemptions do affect bankruptcy demand. Ashcraft, Dick, and Morgan (2007) find that the rush to file Chapter 7 just before the bankruptcy abuse reform (Chart 2) was highest among states with riskier borrowers and high exemptions. Risky households demanded Chapter 7 while supply was high, and they demanded it most where Chapter 7 was most protective of equity owners.

${ }^{12}$ Credit Suisse (2007) analysts first noticed that bankruptcy filers after BAR were less likely to avert foreclosure. They concluded that BAR had affected subprime mortgagors "profoundly." Bernstein (2008) also argues that the surge in foreclosures might be partly attributable to BAR. He does not provide evidence, however. 
Chart 4

Before BAR, Mortgage Performance Improves

Relative to Credit Card Performance When

Bankruptcy Filings Increase

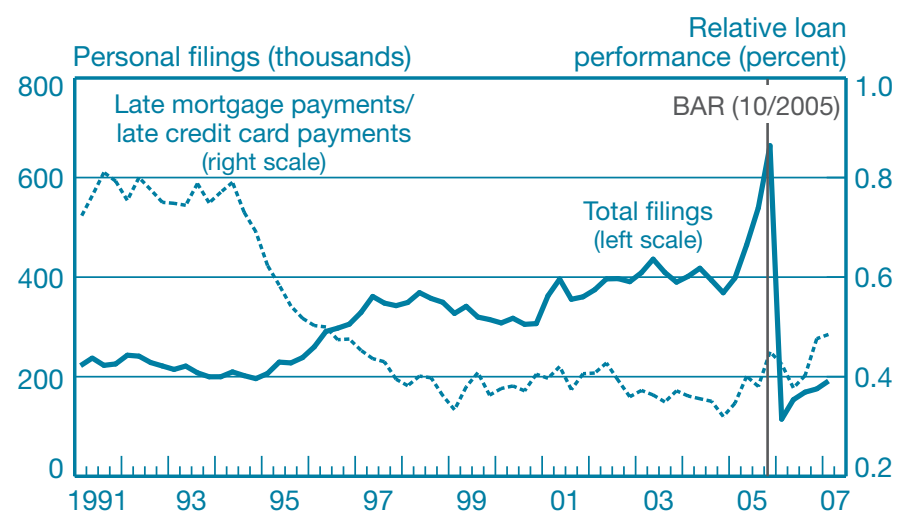

Sources: U.S. courts (bankruptcy filings); banks' Reports of Condition and Income (loan performance data).

Notes: BAR is bankruptcy abuse reform. Residential real estate loans include open- and closed-ended loans secured by one-to-four-family residential properties. Total filings are the number of personal filings under Chapters 7 and 13 each quarter. Relative loan performance is the share of residential real estate loans past due/the share of credit card loans past due, where past due is defined as late ninety or more days or nonaccruing.

a way for cash-flow-constrained debtors to stay current on their mortgage. Relative performance is measured by the ratio of past due mortgages to past due credit card loans on the books of banks. Although other factors are driving the relative performance of Chapter 7 filings, the predicted negative relationship is clear. Before BAR, the correlation between filings and relative performance was $-0.80(p<.01)$; after the reform, the correlation was $0.66(p=0.16)$.

While the circumstantial evidence above is suggestive, it is far from definitive. What remains to be shown is that this evidence is not just coincidental. BAR took effect at the same time in every state, and other factors-namely, home price appreciation-changed at the same time. To rule out the possibility that Chart 1 and the circumstantial evidence are just coincidental, we rely on a cross-sectional identification strategy that reveals the states where BAR should have had the biggest impact.

\section{BAR Is More Likely to Bind in High-Exemption States}

We use a stylized example to demonstrate that BAR is more likely to bind, and thus increase foreclosures, in states with higher home equity exemptions. The intuition is that Chapter 7 is more protective in high-exemption states, so limiting access to it will matter more.

Consider two people who are identical, except one lives in Alabama, where the home equity exemption is $\$ 5,000$, and the other lives in Maryland, where the exemption is zero (Table 2). Both have $\$ 5,000$ of equity in their homes. For whatever reason, both find themselves income constrained in the sense that their current income after taxes and expenses cannot sustain their preferred rate of consumption. We present in Table 3 their hypothetical monthly budgets.

As Caher and Caher (2006) point out, filing Chapter 7 is (or was) a potential solution for debtors in this predicament, though the appeal depends crucially on the debtor's home equity relative to the home equity exemption in his or her state. If the Maryland borrower filed Chapter 7, his credit card debt would not be discharged; even under Chapter 7 protection, the judge would order him to sell ("liquidate") his house to settle his credit card debt. Absent protection from credit card lenders, the Maryland borrower seems unlikely to "demand"

We use a stylized example to demonstrate that BAR is more likely to bind, and thus increase foreclosures, in states with

higher home equity exemptions. The

intuition is that Chapter 7 is more

protective in high-exemption states, so

limiting access to it will matter more.

Chapter 7 as way of relaxing his cash-flow constraint and avoiding foreclosure. In contrast, if the Alabama borrower filed Chapter 7, all of her credit card debt would be discharged and she would keep her $\$ 5,000$ in home equity. The Alabama borrower seems more likely to demand Chapter 7 than the Maryland borrower as a way to relax her cash-flow constraint and avoid foreclosure. Having her credit card debt discharged would free up $\$ 500$ per month in income that she could put toward her mortgage payment. After BAR, both borrowers could find their options limited. If both fail the means test, Chapter 7 is not available to them. The key point, however, is that the lost option of Chapter 7 matters more to the Alabama borrower, because the Maryland borrower was less likely to demand Chapter 7 before BAR.

Table 4 provides a stylized example of how the BAR means test is more likely to bind and thus drive up foreclosures in states with higher home equity exemptions. The table reports hypothetical but realistic indicators of the relative probability 
TABLE 2

States’ Home Equity Bankruptcy Exemptions, Median Home Prices, and Ratios, Sorted by Exemption

\begin{tabular}{|c|c|c|c|c|c|c|c|}
\hline State & Exemption & Price & Ratio & State & Exemption & Price & Ratio \\
\hline Maryland & 0 & 326 & 0 & Colorado & 45 & 231 & 0.17 \\
\hline New Jersey & 0 & 362 & 0 & California & 50 & 485 & 0.10 \\
\hline Pennsylvania & 0 & 162 & 0 & Delaware & 50 & 213 & 0.15 \\
\hline Alabama & 5 & 136 & 0.03 & Idaho & 50 & 164 & 0.28 \\
\hline Kentucky & 5 & 124 & 0.03 & New York & 50 & 284 & 0.18 \\
\hline Ohio & 5 & 128 & 0.02 & Alaska & 54 & 204 & 0.25 \\
\hline South Carolina & 5 & 158 & 0.03 & Connecticut & 75 & 313 & 0.24 \\
\hline Tennessee & 5 & 144 & 0.03 & Mississippi & 75 & 124 & 0.52 \\
\hline Virginia & 5 & 279 & 0.01 & Vermont & 75 & 182 & 0.38 \\
\hline Illinois & 7.5 & 224 & 0.03 & North Dakota & 80 & 120 & 0.49 \\
\hline Georgia & 10 & 152 & 0.05 & Montana & 100 & 156 & 0.50 \\
\hline North Carolina & 10 & 160 & 0.05 & New Hampshire & 100 & 220 & 0.33 \\
\hline Wyoming & 10 & 154 & 0.06 & Arizona & 150 & 256 & 0.57 \\
\hline Nebraska & 12.5 & 128 & 0.09 & Minnesota & 200 & 188 & 0.87 \\
\hline Indiana & 15 & 113 & 0.11 & Rhode Island & 200 & 280 & 0.63 \\
\hline Missouri & 15 & 129 & 0.10 & Nevada & 350 & 327 & 1.07 \\
\hline Hawaii & 20 & 496 & 0.06 & Massachusetts & 500 & 366 & 1.50 \\
\hline Utah & 20 & 173 & 0.10 & Arkansas & Unlimited & 113 & Unlimited \\
\hline Louisiana & 25 & 137 & 0.14 & Washington, D.C. & Unlimited & 391 & Unlimited \\
\hline Oregon & 25 & 235 & 0.10 & Florida & Unlimited & 266 & Unlimited \\
\hline West Virginia & 25 & 148 & 0.09 & Iowa & Unlimited & 123 & Unlimited \\
\hline Miami & 30 & 145 & 0.18 & Kansas & Unlimited & 137 & Unlimited \\
\hline New Mexico & 30 & 165 & 0.16 & Oklahoma & Unlimited & 110 & Unlimited \\
\hline Maine & 35 & 195 & 0.18 & South Dakota & Unlimited & 115 & Unlimited \\
\hline Washington & 40 & 260 & 0.13 & Texas & Unlimited & 136 & Unlimited \\
\hline Wisconsin & 40 & 161 & 0.25 & Mean $^{\mathrm{a}}$ & 60.56 & 206 & 0.24 \\
\hline
\end{tabular}

Sources: State websites (exemptions); Moodys.com (median home prices).

Notes: Exemption is the dollar amount of home equity that unsecured lenders cannot claim under bankruptcy; price is the state median.

Exemption and price are in thousands of dollars at 2005:4. The correlation between exemption and exemption/home price $=0.87$.

${ }^{\mathrm{a}}$ Excludes states with unlimited exemptions.

TABLE 3

Hypothetical Monthly Budget of Cash-FlowConstrained Debtor in Sample States

\begin{tabular}{lr}
\hline Income after taxes & $\$ 3,000$ \\
\hline Preferred consumption & $\$ 2,000$ \\
\hline Secured debt payments (mortgage) & $\$ 1,000$ \\
Unsecured debt payments (credit card) & $\$ 500$ \\
$\quad$ Deficit & $\$ 500$
\end{tabular}

TABLE 4

Probability that a Filer in Sample States Demands Chapter 7, before and after BAR

\begin{tabular}{lccc} 
& $\begin{array}{c}\text { Before } \\
\text { BAR }\end{array}$ & $\begin{array}{c}\text { After } \\
\text { BAR }\end{array}$ & $\begin{array}{c}\text { Difference } \\
\text { (before - after) }\end{array}$ \\
\hline $\begin{array}{c}\text { Alabama debtor } \\
\text { (high home equity exemption) }\end{array}$ & $\rho$ & 0 & $-\rho$ \\
$\begin{array}{c}\text { Maryland debtor } \\
\text { (low home equity exemption) }\end{array}$ & $\rho-\delta$ & 0 & $-\rho+\delta$ \\
$\begin{array}{c}\text { Difference-in-difference } \\
\text { (high - low exemption) }\end{array}$ & $\delta$ & 0 & $-\delta$
\end{tabular}

Note: BAR is bankruptcy abuse reform. 
that the Maryland borrower and the Alabama borrower would demand Chapter 7 to avoid foreclosure before and after the reform.

Suppose that before BAR, the Alabama borrower files Chapter 7 with probability $p \geq 0$. Suppose further that the Maryland borrower is $\delta$ percent less likely to file Chapter 7 because of the low exemption there. After BAR, we assume neither borrower can file Chapter 7 because neither passes the means test. Because the Maryland borrower was less likely to file Chapter 7 before BAR, his demand declines by less than the demand of the Alabama borrower. The difference-indifference in their demand-that is, the difference in demand before and after BAR in the high-exemption state less the difference in demand before and after BAR in the lowexemption state-is $-\delta .{ }^{13}$ Because Chapter 7 demand declines more in the high-exemption state, we expect foreclosures to rise more in those states. We test that prediction in our analysis below.

The example above suggests that cash-flow-constrained Chapter 7 filers are more likely to remain constrained after BAR and thus more likely to face foreclosure. Because highexemption states will have a larger fraction of constrained filers, we venture three hypotheses:

1. The surge in subprime mortgage foreclosure rates since BAR took effect will be higher in high-exemption states.

2. Any change in prime mortgage foreclosures since BAR will be invariant to state exemptions. Prime mortgagors are, by definition, unlikely to demand bankruptcy protection, so BAR is unlikely to bind.

3. Any increase in unsecured consumer credit delinquency rates since BAR will be lower in higher exemption states.

The third hypothesis follows from the fact that constrained Chapter 7 filers are more likely to have to continue making payments on unsecured debts after BAR, so the delinquency rate on unsecured debts in high-exemption states would be expected to fall relative to the rate in low-exemption states.

\section{Regression Model and Findings}

We test our predictions by estimating difference-in-difference regressions:

$$
\begin{aligned}
Y_{s t}=\alpha & +\sum_{s=1}^{N-1} \alpha_{s} D_{s}+\sum_{t=1}^{T-1} \alpha_{t} D_{t}+\beta X_{s t}+\gamma B A R_{t} E X_{s} \\
& +\delta B A R_{t} U N L I M I T E D E X_{s}+\varepsilon_{s t} .
\end{aligned}
$$

\footnotetext{
${ }^{13}$ An analogy might be even simpler than the stylized example. If the state speed limit is 60 in one state and 70 in another, lowering the federal speed limit from 75 to 65 would presumably limit demand for speed more in the state with the higher speed limit.
}

The dependent variable $Y_{s t}$ is the foreclosure rate on subprime or prime mortgages, or the delinquency rate on personal loans in state $s$ at time $t . X_{s t}$ represents four variables that might be correlated with foreclosure or delinquency rates: median home price appreciation (the year-over-year growth rate), the unemployment rate (seasonally adjusted), logged real percapita income, and the real per-capita income growth rate (year-over-year).

We include only contemporaneous values of those control variables, but we have confirmed our main results using lagged values as well (see robustness tests below). $B A R_{t}$ is a dummy variable equal to 0 for $t$ on or before 2005:4 and equal to 1 for $t$

Average annual house price appreciation over the seven quarters before BAR was 8 percent higher than appreciation over the seven quarters following $B A R$, implying

\section{7,689 more subprime foreclosures} outstanding per quarter since the reform.

after that date. $E X_{s}$ is the single-filer home equity exemption in state $s$ at 2005:4 divided by the median home price in state $s$ at 2005:4. UNLIMITEDEX $X_{s}=1$ if the exemption in state $s$ at 2005:4 was unlimited, 0 otherwise. ${ }^{14} \mathrm{We}$ "freeze" exemptions at their 2005:4 levels to avoid endogeneity between exemptions and foreclosure rates. We scale exemptions in case a given exemption in say, California, provides less protection than the same exemption in Idaho. Using unscaled exemptions does not change our main results in any important way (see robustness discussion). Scaled and unscaled exemptions are reported in Table 2. We collect the exemptions data from state legislative websites to ensure their accuracy as of 2005:4. To control for constant differences in the dependent variables across states, we include a matrix of fifty dummy variables (one for each state, plus Washington, D.C., less an omitted state). These state-fixed effects allow for differences in the average rate of foreclosures across states attributable, for example, to differences in foreclosure protection and credit culture. To control for constant differences in the dependent variable over time, we include a sequence of dummy variables for all but one quarter-year in the sample period. These time-fixed effects control for macroeconomic factors, such as interest rates and the aggregate business cycle. It is important to include these fixed effects, but we do not report the roughly 100 associated coefficients. Note that because the regressions include fixed effects, the "own" effects of BAR, EX, and UNLIMITEDEX on foreclosures are unidentified. The coefficients on the

${ }^{14} E X_{s}=0$ when $U N L I M I T E D E X_{s}=1$. 
TABle 5

Subprime Mortgage Foreclosures Rise after BAR in High-Exemption States;

Personal Loan Delinquency Rates Fall

Dependent Variable

Mortgage Foreclosure Rate

$\begin{array}{ccc}\text { Subprime } & \text { Personal Loan } \\ \text { Delinquency Rate }\end{array}$

BAR $\times$ exemption
BAR $\times$ unlimited exemption

House price appreciation

Unemployment rate

$\log ($ per-capita income)

Per-capita income, annual growth

Constant

Observations

Adjusted $\mathrm{R}^{2}$
(1)

(2)

$2.85^{* * *}$

$(0.71)$

0.81

$(0.87)$
$2.09^{* * *}$

$(0.68)$

0.77

$(0.71)$

$-0.11^{* * *}$

$(0.02)$

0.47

$(0.30)$

$-9.27$

(9.14)

0.09

$(0.07)$

96.21

(94.75)

1,989

0.63
(3)

0.07

$(0.08)$

0.04

(0.09)

(a)

Source: Authors' calculations.

Notes: BAR is bankruptcy abuse reform. Reported are regression coefficients (robust standard errors, clustered at the state level) estimated using ordinary least squares and state data from 1998:1 to 2007:3. BAR $=0$ on or before 2005:4 and 1 after. Exemption = home equity exemptions in the state at 2005:4/median home price in the state at 2005:4. Unlimited exemption $=1$ for states with unlimited homestead exemption at 2005:4, zero for other states. All regressions include state- and year-quarter-fixed effects.

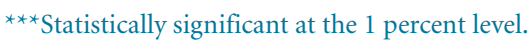

${ }^{* *}$ Statistically significant at the 5 percent level.

${ }^{*}$ Statistically significant at the 10 percent level.

interactions-BAR $\mathrm{x} E X$ and $B A R \times$ UNLIMITEDEXmeasure the difference-in-difference of the mean of $Y$. Said differently, those coefficients measure how the difference in the mean of $Y$ after BAR differs with EX or UNLIMITEDEX. We predict positive coefficients on both variables in the subprime regression, smaller or zero coefficients in the prime regression, and negative coefficients in the personal loan regression.

We estimate the regressions using ordinary least squares and a panel of state-quarter data from 1998:1 to 2007:3. The foreclosure data are from the National Delinquency Survey published by the Mortgage Bankers Association (MBA). The MBA collects its data from 120 lenders with 44 million loans on one-to-four-unit residential properties. ${ }^{15}$ The American Bankers Association collects its data from a panel of 450 banks across the country. Summary statistics and sources for all regression variables are presented in the appendix.

\footnotetext{
${ }^{15}$ See http://www.mortgagebankers.org/NewsandMedia/PressCenter/ 56555.htm.
}

Regression coefficients and standard errors (clustered by state) are reported in Table 5. The signs of the key coefficients are as predicted. BAR $\mathrm{x} U N L I M I T E D E X$ is statistically insignificant, contrary to our hypothesis, but $B A R \times E X$ is significantly positive in the subprime foreclosure regression and significantly negative in the personal loan delinquency regression. ${ }^{16}$ Both prime and subprime foreclosure rates are negatively related to home price appreciation and unemployment, as one would expect, but only subprime foreclosures depend on BAR.

The regression estimates imply that the impact of BAR on subprime foreclosures is smaller, but of the same order, as the impact of slower house price appreciation. The coefficient on $B A R \times E X$ in column 2 indicates that for a state with average home equity exemptions/median home prices, the average subprime foreclosure rate over the seven quarters after BAR

${ }^{16}$ We lack a good explanation for why the unlimited-exemption states (and Washington, D.C.) do not fit the regression line. 
was 11 percent higher than the average rate over the period before BAR. ${ }^{17}$ That translates to about 29,000 more subprime foreclosures nationwide per quarter attributable to BAR. ${ }^{18}$ By comparison, a standard-deviation decrease in home price appreciation increases the foreclosure rate 13.7 percent relative to the average. Average annual house price appreciation over the seven quarters before BAR was 8 percent higher than appreciation over the seven quarters following BAR, implying 47,689 more subprime foreclosures outstanding per quarter since the reform. ${ }^{19}$ Thus, the impact of home price deprecation is larger, but the impact of BAR is of the same order of magnitude.

The main results in Table 5 are robust to several alternative specifications. The inclusion of four lags of home price appreciation and all other economic variables does not appreciably alter the significance of the coefficient for $B A R \mathrm{x}$ $E X$. We also obtain similar results when we control for the share of subprime mortgages that are secured and the share with adjustable rates (though those data are available only after 2004:1). For those regressions, we find that the share of subprime mortgages that were securitized was positively and significantly related to the subprime foreclosure rate, which is consistent with the evidence in Keys et al. (2010) that securitization agency problems contributed to foreclosures. The size and significance of the BAR x EX coefficient do not change appreciably when we add those extra controls, however. Use of exemption levels that are not scaled by the median home price does not materially change the results.

We also find that omitting those states that experienced the highest foreclosure rates-Arizona, California, Florida, and Nevada-actually magnifies the impact of BAR on subprime foreclosures. ${ }^{20}$ While we believe that the robust coding we have used for unlimited-exemption states is the preferable specification, simply dropping these states does not appreciably alter the coefficient estimates on $B A R \times E X$.

\footnotetext{
17 The coefficient estimate in regression model 2 implies that the mean foreclosure rate in a state with a mean exemption level $(\$ 25,245)$ was 51.5 (2.04 x 25.245) basis points higher after BAR than before, an increase of 11 percent relative to the mean foreclosure rate before BAR (4.64 percent).

${ }^{18}$ The average number of subprime mortgages outstanding over the post-BAR period was $5,545,799$, so an increase of 51.5 basis points in the foreclosure rate in a typical (median-exemption) state implies 28,561 (.00515 x 5,545,799) more subprime foreclosures per quarter as a result of BAR.

${ }^{19}$ A standard-deviation increase in the unemployment rate increases the foreclosure rate about 13.4 percent. Unemployment rates decreased almost 70 basis points on average since BAR, implying 20,059 fewer foreclosures per quarter.

${ }^{20}$ With those states excluded, the coefficients (standard errors) on BAR $\mathrm{x} E X$ in the subprime foreclosure regression models ( 1 and 2) become 3.55 (0.71) and $2.68(0.70)$. The coefficients in the prime foreclosure and personal loan delinquency regression do not change appreciably when the four states are excluded.
}

\section{Conclusion}

Our study suggests that the bankruptcy abuse reform of 2005 may have been one of a number of contributors to the destabilizing surge in subprime foreclosures by shifting risk from credit card lenders to mortgage lenders. The means test component of BAR gives credit card and other unsecured creditors a stronger claim on borrowers' cash flows, thus weakening the (implicit) claims of secured lenders on these funds. By making it harder for borrowers to avoid paying credit card debt, BAR made it more difficult for them to pay their mortgages, so foreclosure rates rose.

Although proponents of the reform may not have anticipated that BAR would have contributed to the surge in foreclosures, observers close to the facts saw the wave coming. Alexis McGee, President of Foreclosure.com, made this prediction six months before the reform took effect:

People get in over their heads by further encumbering their homes with equity lines of credit that are exhausted with purchases of consumer products and services such as cars and expensive vacations. Then, when interest rates rise, and home values stop increasing, they can no longer refinance and file a Chapter 7 bankruptcy petition to wipe out their [unsecured] debts and hold off foreclosure by their lender.... [ [Now] they must file under Chapter 13, and pay off their debt in 60 months or less. Middle income families in this position could face the loss of their homes (Business Wire, April 25, 2005).

\section{McGee was prescient.}

It should be noted that BAR will not necessarily lead to higher foreclosure rates in the steady state. Once borrowers have learned that the bankruptcy rules have changed, they can be expected to reduce their demand for unsecured debt to avoid the bind that BAR creates. If so, the long-run impact of BAR on subprime foreclosures may be negligible. 


\section{ApPENDIX}

\section{Data Sources and Summary Statistics}

\begin{tabular}{|c|c|c|c|c|c|c|}
\hline & Source & Number & Mean & $\begin{array}{l}\text { Standard } \\
\text { Deviation }\end{array}$ & Minimum & Maximum \\
\hline \multicolumn{7}{|l|}{ Dependent variables } \\
\hline Subprime foreclosure rate & Mortgage Bankers Association & 1,989 & $5.74 \%$ & $3.33 \%$ & $0.00 \%$ & $17.03 \%$ \\
\hline Prime foreclosure rate & Mortgage Bankers Association & 1,989 & $0.51 \%$ & $0.28 \%$ & $0.07 \%$ & $2.11 \%$ \\
\hline Sixty-month new auto loan rate & Bankrate.com & 1,734 & $7.06 \%$ & $1.29 \%$ & $3.87 \%$ & $11.75 \%$ \\
\hline Five-year U.S. Treasury & Board of Governors of the Federal Reserve System & 1,734 & $4.41 \%$ & $1.03 \%$ & $2.57 \%$ & $6.59 \%$ \\
\hline auto-Treasury spread & & 1,734 & $2.65 \%$ & $0.65 \%$ & $0.37 \%$ & $6.95 \%$ \\
\hline Personal delinquency rate ${ }^{\mathrm{a}}$ & American Bankers Association & 1,577 & $2.03 \%$ & $0.95 \%$ & $0.13 \%$ & $7.04 \%$ \\
\hline Auto loan delinquency rate, direct & American Bankers Association & 1,546 & $1.75 \%$ & $0.94 \%$ & $0.34 \%$ & $8.38 \%$ \\
\hline Auto loan delinquency rate, indirect & American Bankers Association & 1,373 & $1.87 \%$ & $1.01 \%$ & $0.11 \%$ & $8.39 \%$ \\
\hline \multicolumn{7}{|l|}{ Independent variables } \\
\hline Single household exemption & Code law for each state & 1,989 & $\$ 39,803$ & $\$ 67,161$ & $\$ 0$ & $\$ 550,000$ \\
\hline Median house price & Federal Home Finance Board & 1,989 & $\$ 184,178$ & $\$ 72,663$ & $\$ 71,000$ & $\$ 620,000$ \\
\hline exemption/median house price & & 1,989 & 0.21 & 0.30 & 0.00 & 1.75 \\
\hline Unemployment rate & BLS & 1,989 & $4.67 \%$ & $1.17 \%$ & $2.10 \%$ & $9.70 \%$ \\
\hline House price appreciation ${ }^{\mathrm{b}}$ & Moody's Economy.com & 1,989 & $6.13 \%$ & $5.97 \%$ & $-7.88 \%$ & $51.57 \%$ \\
\hline Real per-capita income in $2005: 1$ & U.S. Census Bureau, BEA, BLS & 1,989 & $\$ 32,389$ & $\$ 5,354$ & $\$ 11,667$ & $\$ 56,951$ \\
\hline Log(real per-capita income $)$ & & 1,989 & 10.37 & 0.16 & 9.36 & 10.95 \\
\hline Change in real per-capita income $\mathrm{b}^{\mathrm{b}}$ & & 1,989 & $1.85 \%$ & $4.33 \%$ & $-57.90 \%$ & $158.56 \%$ \\
\hline
\end{tabular}

Notes: Data are from 1998:1 to 2007:3 for the fifty states and Washington, D.C., except where noted. BLS is Bureau of Labor Statistics; BEA is Bureau of Economic Analysis.

${ }^{\mathrm{a}}$ Data are incomplete for some states.

${ }^{\mathrm{b}}$ Year-over-year percentage change. 


\section{REFERENCES}

Ashcraft, A. B., A. Dick, and D. P. Morgan. 2007. "The Bankruptcy Abuse Prevention and Consumer Protection Act: Means-Testing or Mean Spirited?” Federal Reserve Bank of New York Staff Reports, no. 279, March.

Berkowitz, J., and R. Hynes. 1999. "Bankruptcy Exemptions and the Market for Mortgage Loans." Journal of LAw AND Economics 42, no. 2 (October): 809-30.

Bernstein, D. P. 2008. "Bankruptcy Reform and Foreclosure." Working paper, July. Available at http://papers.ssrn.com/sol3/ papers.cfm?abstract_id=1154635.

Caher, J. P., and J. M. Caher. 2006. Personal Bankruptcy Laws for Dummies. 2nd ed. Hoboken, N.J.: Wiley.

CCH. 2005. "Bankruptcy Overhaul Enacted-New Rules for Bankruptcy Implemented.” CCH BANKruptcy Reform ACT Briefing: Bankruptcy Abuse Prevention and Consumer Protection Act of 2005. Special report, April. Available at http://www.cch.com/bankruptcy/bankruptcy_04-21.pdf.

Credit Suisse. 2007. “Subprime Heat Update.” Fixed-Income Research, March 8.

Dell'Ariccia, G., D. Igan, and L. Laeven. 2008. "Credit Booms and Lending Standards: Evidence from the Subprime Mortgage Market.” IMF Working Paper no. 08/106, April. Available at http://www.imf.org/external/pubs/ft/wp/2008/wp08106.pdf.
Demyanyk, Y., and O. Van Hemert. 2007. "Understanding the Subprime Mortgage Crisis." Unpublished paper, Federal Reserve Bank of St. Louis.

Gerardi, K., H. Rosen, and P. S. Willen. 2007. "Subprime Outcomes: Risky Mortgages, Homeownership Patterns, and Foreclosures." Unpublished paper, Federal Reserve Bank of Boston, July.

Keys, B. J., T. Mukherjee, A. Seru, and V. Vig. 2010. "Did Securitization Lead to Lax Screening? Evidence from Subprime Loans.” Quarterly Journal of Economics 125, no. 1 (February): 307-62.

Mian, A., and A. Sufi. 2009. "The Consequences of Mortgage Credit Expansion: Evidence from the U.S. Mortgage Default Crisis." Quarterly Journal of Economics 124, no. 4 (November): 1449-96.

Morgan, D. P., B. Iverson, and M. Botsch. 2008. "Seismic Effects of the Bankruptcy Reform." Federal Reserve Bank of New York Staff Reports, no. 358, November.

White, M. J. 2006. "Abuse or Protection? Consumer Bankruptcy Reform under 'BAPCPA.’” Economie Publique, no. 18-19: 3-27.

2007. "Bankruptcy Reform and Credit Cards.” JournaL of Economic Perspectives 21, no. 4 (fall): 175-200.

White, M. J., and N. Zhu. 2008. "Saving Your Home in Chapter 13 Bankruptcy.” NBER Working Paper no. 14179, July.

The views expressed are those of the authors and do not necessarily reflect the position of the Federal Reserve Bank of New York, the Federal Reserve System, Harvard University, or the University of California at Berkeley. The Federal Reserve Bank of New York provides no warranty, express or implied, as to the accuracy, timeliness, completeness, merchantability, or fitness for any particular purpose of any information contained in documents produced and provided by the Federal Reserve Bank of New York in any form or manner whatsoever. 